\title{
Analisa Yuridis Penetapan Covid 19 Sebagai Kedaruratan Kesehatan Masyarakat Ditinjau Dari Peraturan Perundang-Undangan di Indonesia
}

\author{
Rela Rizki Pratiwi, Hasrina Nurlaily, Demi Artha \\ Fakultas Hukum \\ Universitas Trunojoyo Madura \\ rizki.rela@gmail.com
}

\begin{abstract}
Abstrak
Covid-19 merupakan nama penyakit yang disebabkan oleh virus corona yang beberapa waktu ini menyerang dan menimbulkan banyak kekhawatiran masyarakat karena penularannya yang pesat. Akibat dari adanya virus ini adalah terdapat peningkatan secara signifikan penderita yang terinfeksi dan perlu adanya suatu kebijakan dari Pemerintah yang dapat segera menghentikan penularan virus tersebut. Menurut World Health Organization Covid-19 merupakan wabah yang kemudian statusnya berubah menjadi pandemi. Artinya jika dikaitkan dengan Undang-Undang tentang Wabah Penyakit Menular, Covid-19 dapat dikategorikan sebagai wabah penyakit yang menular dikarenakan akibat adanya penyakit ini menularkan kepada banyak orang sehingga penderita Covid-19 semakin meningkat secara nyata. Berdasarkan hal tersebut, ini dianggap sebagai darurat kesehatan. Penelitian ini merupakan penelitian hukum normatif. Penelitian ini menggunakan bahan hukum primer dan bahan hukum sekunder serta menggunakan langkah-langkah penelitian yang meliputi menentukan isu hukum, menentukan aturan hukum yang relevan, menganalisa, dan menginterpretasikannya untuk ditarik kesimpulan.
\end{abstract}

Kata kunci : Covid-19, virus corona, darurat kesehatan

\begin{abstract}
Covid-19 is the name of a coronavirus disease which has been attacking for some time and has caused much public concern because of rapid transmission. As a result of this virus there is a significant increase need for government policies that can immediately stop the transmission the virus. According to the World Health Organization, Covid-19 was a plague which later turned into a pandemic status. This means that associated with the Law on Infectious Disease, Covid-19 is categorized as infectious disease outbreak because this disease is transmitted to many people. Based on this, this is considered a health emergency.
\end{abstract}

Keywords: Covid-19, corona virus, health emergency. 


\section{Pendahuluan}

Di awal tahun 2019, dunia mengalami masalah pada kesehatan akibat virus yang menyebar berasal dari Wuhan, Tiongkok. Corona Virus adalah suatu kelompok virus yang dapat mengakibatkan penyakit pada manusia dan juga hewan. Diketahui bahwa beberapa jenis coronavirus menyebabkan infeksi pada saluran pernafasan pada manusia. Mulai dari batuk pilek sampai ke yang lebih serius seperti Middle East Respiratory (MERS) dan Severe Acute Respiratory Syndrome (SARS). penyakit yang baru ditemukan ini disebut dengan COVID-19.

(who.int/indonesia/news/novel-

coronavirus/qa-for-public)

Covid19 adalah nama penyakit yang muncul dan menjadi masalah besar di seluruh dunia, begtiu juga negara Indonesia. Penyebaran virus ini seringkali terjadi antara manusia dengan manusia lainnya melalui tetesan cairan dari mulut dan hidung saat orang yang terinfeksi sedang batuk maupun bersin. Bentuk penularannya sama persisi dengan penularan flu pada umumnya. Tetesan cairan tersebut bisa jatuh, menempel, dan tertinggal pada bagian tubuh orang lain yang berada didekatnya bahkan terserap ke dalam paru-paru orang lain melalui hidung. Hingga saat ini belum ditemukan vaksin yang jelas untuk mencegah seseorang terkena virus corona. Para pasien yang terinveksi virus corona ini perlu mendapat perawatan medis untuk meringankan keadaan dan menghilangkan gejala penyakit ini.. (who.int/indonesia/news/novelcoronavirus/qa-for-public)

Penyebarannya sampai ke 34 Provinsi di Indonesia dan semakin hari bertambah kasus kematian akibat dari virus corona. Kemudian sejak saat itu kasus virus corona semakin bertambah banyak hingga saat ini. Dan makin bertambah rumit untuk ditangani karena banyak aturan yang sulit diterima masyarakat. Menurut UndangUndang Corona virus dapat dikategorikan sebagai wabah penyakit menular karena secara nyata banyak yang tertular. Oleh 
karena itu dianggap sebagai darurat kesehatan.(https://m.detik.com/news /berita/d-4991485/kapansebenarnya-corona-pertama-masukri). Selanjutnya dokter akan melakukan pemeriksaan fisik dan pemeriksaan darah. Lebih serius lagi, dokter akan melakukan pemeriksaan dahak, mengambil sempel dari tenggorokan, atau spesimen pernapasan yang lainnya. Untuk kasus yang telah diduga terinfeksi corona, dokter akan melakukan test PCR (Polymerase Chain Reaction) dengan melakukan pemeriksaan swab tenggorokan, DPL, fungsi hepar, dan fungsi ginjal. (halodoc.com: 2020)

Dari hari ke hari, kasus Covid-19 terus bertambah. Bahkan setiap harinya bisa bertambah sekitar 1.000 kasus. Penambahan tersebut mengakibatkan jumlah kasus saat ini mencapai 45.000 kasus sejak kasus pertama diumumkan Presiden Jokowi. Penambahan kasus tertinggi terjadi di Jawa Timur. Kemudian di susul DKI Jakarta. Menurut juru bicara Pemerintah untuk penanganan Covid-19, ada dua hal yang menyebabkan terus bertambahnya kasus ini adalah masih banyak orang berkeliaran orang yang tanpa gejala di masyarakat. Dan kemudian karena masih banyak orang yang rentan tertular corona namun tidak disiplin dan patuh. Banyak sekali orangorang yang tidak menjaga jarak dan tidak memakai masker saat keluar rumah. Disamping itu sulit untuk menerapkan kebiasaan mencuci tangan dengan baik.

Berdasarkan uraian diatas maka akan dilakukan analisis yuridis mengenai penetapan Covid-19 sebagai kedaruratan masyarakat dengan ditinjau melalui peraturan perundang-undangan di Indonesia.

\section{Rumusan Masalah}

Bagaimana analisis yuridis penetapan Covid-19 sebagai kedaruratan kesehatan masyarakat ditinjau dari peraturan perundangundangan di Indonesia?

\section{Metode Penelitian}

Metode penelitian yang digunakan adalah metode pendekatan yuridis normatif yang bersumber dari data primer dan data sekunder. Guna mengumpulkan data dilakukan dengan penelitian bersifat deskriptif analisis. Yang diperoleh melalui 
peraturan perundang-undangan dan bahan referensi lainnya.

Pendekatan yang digunakan adalah Undang-Undang (Statute Approach) yakni menelaah undangundang. (Pieter Mahmud Marzuki, Penelitian Hukum, Kencana, 35).

Penyebaran Virus Corona (Covid19) Sebagai Pandemi Global dan Jaminan Hukum Terhadap Mayarakat

Pada awal ditemukannya virus ini berasal dari kasus pneumonia yang misterius di wuhan, China, yang dilaporkan pertama kali pada organisasi kesehatan dunia World Healt Organization (WHO) pada 31 Desember 2019. Virus corona dikenal Awalnya, penyakit ini dinamakan sementara sebagai 2019 novel coronavirus (2019-nCoV), kemudian WHO mengumumkan nama baru pada 11 Februari 2020 yaitu Coronavirus Disease (COVID19) yang disebabkan oleh virus Severe Acute Respiratory Syndrome Coronavirus-2

(SARS-CoV-2).

(World Health Organization. Naming the coronavirus: www.who.int/emergencies/diseases/ novel-coronavirus-2019/ pada senin, 25 Mei 2020)

Virus corona kemudian dinyatakan sebagai pandemi global pada hari Rabu, 11 Maret 2020. Pandemi sendiri berhubungan dengan penyebaran geografis dan digunakan untuk menggambarkan penyakit yang menyerang seluruh negara atau seluruh dunia. Penetapan virus corona sebagai pandemi penting dilakukan untuk mengarahkan respons baik kepada pemerintah, lembaga yang berkaitan, dan terlebih juga masyarakat untuk mengendalikan dan mencegah penyakit dengan lebih baik. (dilansir pada www.halodoc.com, selasa 26 Mei 2020)

Penetapan virus corona sebagai pandemi berdampak pada beberapa aspek di kehidupan masyarakat dunia, salah satunya pemerintah harus mengeluarkan beberapa peraturan untuk memutus rantai penyebaran virus corona. Hal tersebut sangat berdampak pada perekonomian, kesehatan, medis, sosial budaya, keamanan dan ketertiban, serta hal-hal lain yang 
turut menjadi pertimbangan pemerintah untuk tetap mempertahankan beberapa aspek di kehidupan masyarakat akan tetapi juga berupaya untuk mencegah penyebaran Covid-19, karena negara harus berperan untuk menjamin kesehatan masyarakat.

\section{Negara} wajib

mengumumkan wilayah yang menjadi sumber penularan wabah / penyakit dan mengungkapkan hal-hal yang brpotensi dapat menyebabkan penularan atau sebagai sumber penularan suatu wabah / penyakit. Kesehatan adalah salah satu kebutuhan dasar manusia. Konstitusi World Health Organization (WHO) 1948 telah menegaskan pula bahwa "memperoleh derajat kesehatan yang setinggi-tingginya adalah suatu hak asasi bagi setiap orang" (the enjoyment of the highest attainable standard of health is one of the fundamental rights of every human being). Istilah yang digunakan bukan "human rights", tetapi "fundamental rights", yang kalau kita terjemahkan langsung ke Bahasa Indonesia menjadi "Hak hak Dasar".

Perubahan Kedua UndangUndang Dasar 1945, kesehatan ditegaskan sebagai bagian dari hak asasi manusia. Dalam Pasal 28H ayat (1) dinyatakan, bahwa: "Setiap orang berhak hidup sejahtera lahir dan batin, bertempat tinggal, dan mendapat lingkungan hidup yang baik dan sehat serta berhak memperoleh pelayanan kesehatan." Masuknya ketentuan tersebut ke dalam Undang-Undang Dasar 1945, menggambarkan merupakan hak hukum (legal rights) yang tentunya dijamin oleh negara.

\section{Penyebaran Covid-19 Sebagai Wabah Penyakit Menular di}

\section{Indonesia}

Indonesia Covid-19 pertama kali ditemukan pada daerah Depok, Jawa Barat yang menyerang kepada dua orang pada awal bulan Maret tahun 2020. (dilansir pada berita kompas.com dengan link

${ }^{1}$ Eleanor D. Kinney, "The International Human Right to Health", dalam Indiana Law Review, Vol 34, 1559, hlm. 
https://nasional.kompas.com/read/20

20/03/03/06314981/fakta-lengkap-

kasus-pertama-virus-corona-di

indonesia, Kamis, 17 September

2020). Penyebaran ini sangat cepat dan semakin meningkat. Sifat virus ini sangat cepat menyebarnya dan didukung dengan faktor lain yaitu dihiraukannya himbauan pemerintah oleh masyarakat. Data yang dapat dilihat saat ini Indonesia merupakan tertinggi nomor dua se Asia Tenggara dengan jumlah terkonfirmasi positif Covid-19 yaitu sebanyak 221.523 kasus. (dilansir pada berita liputan6 dengan link: https://www.liputan6.com/global/rea d/4356731/kasus-covid-19-

indonesia-tertinggi-ke-2-di-asiatenggara-filipina-nomor-1, Kamis, 17 September 2020). Karena semakin menyebarnya virus ini dan membahayakan kemudian Covid-19 ini dikenal menjadi wabah penyakit yang membahayakan bagi masyarakat. Akibat meningkatnya kematian maka di Indonesia hal ini menjadi hal kejadian luar biasa. Kejadian luar biasa yaitu kejadian dimana munculnya atau meningkatnya kesakitan atau kematian yang memiliki makna secara epidemiologis pada daerah dalam waktu tertentu, serta merupakan situasi yang dapat menjurus pada terjadinya wabah.

Gejala seseorang terinfeksi Covid-19 ini menurut World Health Organizations (WHO) gejala bahwa seseorang telah terinfeksi Covid-19 yaitu diawali dengan batuk, sesak nafas, hingga sulit dalam bernafas. (dilansir pada CNBC Indonesia dengan link: https://www.cnbcindonesia.com/tech /20200331110205-37-148693/simakini-gejala-terinfeksi-corona-menurutwho, Kamis, 17 September 2020). Covid-19 menyebabkan penderita hingga mengalami kematian, sehingga hal ini membuat masyrakat resah, dan Pemerintah Indonesia pun melakukan tindakan dengan segala upaya pencegahan serta mengeluarkan kebijakan. Seseorang dapat dikatakan telah terinfeksi ketika telah terdapat keluhan yang sama dan melalui test Covid-19 serta dinyatakan positif. Pasien yang mengalami keluhan atau telah dari daerah yang terpapar maka selama 14 hari isolasi secara mandiri. 
Namun jika tidak memungkinkan maka akan dilakukan isolasi oleh tenaga medis. Penularan awal mula dari hewan kepada manusia. Namun terus berkembang sehingga dapatt ditularkan dari manusia melalui manusia.

Undang-Undang No. 4 Tahun 1984 tentang Wabah Penyakit Menular tepatnya pada Pasal 1 huruf a menyatakan bahwa "Wabah penyakit menular yang selanjutnya disebut wabah adalah kejadian berjangkitnya suatu penyakit menular dalam masyarakat yang jumlah penderitanya meningkat secara nyata melebihi dari pada keadaan yang lazim pada waktu dan daerah tertentu serta dapat menimbulkan malapetaka". Yang artinya makna malapetaka dalam hal ini yaitu dampak yang diakibatkan sangat berbahaya hingga banyak korban. Sumber penyakit menurut Undang-Undang No. 4 Tahun 1984 tentang Wabah Penyakit Menular yaitu berasal dari manusia, hewan, tumbuhan dan benda-benda yang mengandung dan/.atau tercemar bibit penyakit, serta yang dapat menimbulkan wabah. Didukung dari data Worl Health Organizations (WHO), Covid-19 tidak hanya wabah tetapi pandemi (dilansir pada katakata.co.id, pada hari Senin, 25 Mei 2020). Ditetapkannya Covid-19 sebagai pandemi oleh World Health Organization, artinya penyakit ini telah menyebar diseluruh dunia dan meminta agar pemerintah di setiap negara selalu siap siaga untuk mencegah dan menanganinya (dilansir pada www.cnbcindonesia.com, pada hari Senin, 25 Mei 2020).

Indonesia, semakin meningkatnya dan cepatnya penyebaran ini maka Pemerintah berupaya melakukan upaya penanggulangan. Penanggulangan yaitu upaya yang bertujuan untuk memperkesil adanya kematian, melakukabb pembatasan adanya yang tertular dan tersebarnya penyakit agar wabah tidak semakin meluas penyebarannya. Terkait dengan upaya penanggulangan dapat dilakukan sesuai dalam Pasal 5 Undang-Undang No. 4 Tahun 1984 tentang Wabah Penyakit Menular meliputi “a) penyelidikan epidemiologis; b) pemeriksaan, 
pengobatan, perawatan, dan isolasi penderita, termasuk tindakan karantina; c) pencegahan dan pengebalan; d) pemusnahan penyebab penyakit; e) penanganan jenazah akibat wabah; f) penyuluhan kepada masyarakat; g) upaya penanggulangan lainnya”. Yang mana dalam hal ini juga sangat diperlukan peran aktif masyarakat.

\section{Analisis Yuridis Penetapan Covid-} 19 Sebagai Kedaruratan Kesehatan Masyarakat Ditinjau Dari Peraturan Perundangundangan di Indonesia

Upaya pencegahan yaitu salah satunya tindakan karantina. Hal ini lebih khusus diatur dalam UndangUndang No. 6 Tahun 2018 tentang Kekarantinaan Kesehatan yang menyatakan bahwa "Kekarantinaan Kesehatan adalah upaya mencegah dan menangkal keluar atau masuknya penyakit dan/atau faktor risiko kesehatan masyarakat yang berpotensi menimbulkan kedaruratan kesehatan masyarakat". Karantina merupakan pembatasan kegiatan dengan artian untuk memisahhkan seorang yang terkena atau terpapar penyakit menular yan ditetapkan dalam peraturan perundangundangan walaupun belum terdapat gejala atau sedang ada dalam fase inkubasi baik pemisahan peti kemas, alat atau barang yang diduga terkontaminasi dari seorang yang merupakan sebab adanya penyakit atau sumber kontaminasi lain yang bertujuan untuk mencegah kemungkinan adanya penyebaran kepada orang lain atau barang disekitarnya. Karantina tidak hanya dilakukan di darat saja melainkan juga dapat dilakukan pada laut serta udara. Mengenai karantina laut ini diatur dalam Undang-Undang No. 1 Tahun 1962, LN No. 2, TLN No. 2373 tentang Karantina Laut yang mana undang-undang ini ditujukan untuk menolak serta mencegah keluar masuknya adanya penyakit melalui karantina kapal. Artinya nahkodah pun dilarang untuk menaikkan serta menurunkan penumpang. Selanjutnya terdapat Undang-Undang No. 2 Tahun 1962, LN No. 3, TLN No. 2374 tentang Karantina Udara yang mana melarang pula pesawat udara untuk beroperasi. 
Disimpulkan bahwa adanya karantina dikarenakan adanya suatu penyakit yang menular baik dari seseorang atau barang disekitarnya kepada orang lain. Adapun tujuan kekarantinaa kesehatan ini yaitu 1) melindungi masyarakat dari penyakit, resiko yang dapat menimbulkan kedaruratan kesehatan masyarakat, 2) melakukan pencegahan dan menyangkal penyakit, faktor resiko kesehatan masyarakat yang dapat menimbulkan kedaruratan kesehatan masyarakat, 3) peningkatan ketahanan nasional dalam bidang kesehatan masyarakat, dan 4) pemberian perlindungan serta kepastian hukum bagi masyarakat dan petugas kesehatan. Melihat dari tujuan adanya penyelenggaraan kekarantinaan kesehatan tersebut maka dapat disimpulkan suatu hal dilakukan karantina kesehatan di karenakan terdapat hal yaitu penyakit ataupun faktor resiko yang dapat membahayakan kesehatan masyarakat sehingga menimbulkan kedaruratan kesehatan masyarakat. Pada Pasal 1 ayat (2) UndangUndang No. 6 Tahun 2018 tentang Kekarantinaan

Kesehatan menyebutkan bahwa "Kedaruratan kesehatan masyarakat adalah kejadian kesehatan masyarakat yang bersifat luar biasa dengan ditandai penyebaran penyakit menular dan/atau kejadian yang disebabkan oleh radiasi nuklir, pencemaran biologi, kontaminasi kimia, bioterorisme, dan pangan yang menimbulkan bahaya kesehatan dan berpotensi menyebar lintas wilayah atau lintas negara". Adanya kedaruratan kesehatan masyarakat ini ditetapkan oleh Pemerintah, dikarenakan membahayakan dan meresahakan kessehatan masyarakat sehingga diperlukan penanganan khusus. Selanjutnya dalam Peraturan Menteri Kesehatan No. 1501/MENKES/PER/X/2010 tentang Jenis Penyakit Menular Tertentu Yang Dapat Menimbulkan Wabah Dan Upaya Penanggulangan mengenai jenis penyakit menular yaitu kolera, pes, demam berdarah dengue, campak, polio, difteri, pertusis, rabies, malaria, avian influenza $\mathrm{H} 5 \mathrm{~N} 1, \quad$ antraks, Leptospirosis, hepatitis, influenza A baru (H1N1)/pandemi 2009, meningitis, yellow fever, dan 
Chikungunya. Kemudian jenis lainnya yang di dapat menimbulkan wabah ditetapkan oleh Menteri.

Hal ini sangat berkaitan erat dengan Covid-19. Hal ini telah tepat jika Covid-19 ditetapkan sebagai kedaruratan kesehatan masyarakat. Jika dianalisis pertama dari sifat Covid-19, yaitu virus ini menyebar secara contagious yang hal ini mengacu pada infeksi yang menyebar dengan cepat dalam sebuah jaringan seperti bencana atau flu. Istilah ini digunakan pertama kali pada tahun 1546 oleh Giralamo Fracastor. Dari adanya virus ini terdapat peningkatan signifikan penderita yang terinfeksi tanpa memandang usia (Nailul Mona,2020 : 117-118). Kedua, dikarenakan sifatnya yang contagious artinya penyebaran yang cepat, maka Covid19 menurut World Health Organization merupakan wabah yang kemudian statusnya berubah menjadi pandemi. Artinya jika dikaitkan dengan Undang-Undang No. 4 Tahun 1984 tentang Wabah Penyakit Menular, Covid-19 dapat dikategorikan sebagai wabah penyakit yang menular dikarenakan akibat adanya penyakit ini meluarkan kepada banyak orang sehingga penderita semakin meningkat secara nyata dan menimbulkan banyak permasalahan termasuk di Indonesia. Ketiga, jika di analisis Covid-19 ini penyakit yang bersumber awal dari hewan yang ditularkan pada manusia, kemudian dari manusia ke benda, dan hingga selanjutnya dari benda ke manusia dan akhirnya dari manusia ke manusia, yang mana hal ini telah memuat unsur sumber penyakit yang termaktub dalam Undang-Undang No. 4 Tahun 1984 tentang Wabah Penyakit Menular. Keempat, dari adanya semua hal tersebut kemudian dilakukan penanggulangan khusus hingga tindakan karantina baik mandiri maupun wilayah. Dan jika dikaitkan pada tindakan kekarantinaan kesehatan maka dapat dinilai serta disimpulkan bahwa banyaknya kebijakan yang dikeluarkan mulai dari karantina mandiri dan wilayah, serta Pembatasan Sosial Berskala Besar ini terhadap Covid-19 artinya telah dalam kedaruratan kesehatan masyarakat sebagaimana yang 
termaktub dalam Undang-Undang No. 6 Tahun 2018 tentang Kekarantinaan Kesehatan. Dan terakhir adanya keadaan sedemikian rupa, maka Pemerintah dapat menetapkan bahwa adanya Covid-19 ini merupakan kedaruratan kesehatan masyarakat yaitu Keputusan Presiden Republik Indonesia No. 11 Tahun 2020 tentang Penetapan Kedarutan Kesehatan Masyarakat Corona Virus Disease 2019 (COVID-19) yang menetapkan bahwa Covid-19 sebagai penyakit yang menimbulkan Kedaruratan Kesehatan Masyarakat.

\section{Kesimpulan}

Berdasarkan analisis diatas tersebut maka dapat disimpulkan telah tepat adanya penetapan Covid19 sebagai kedaruratan kesehatan masyarakat dikarenakan sifatnya yang cepat menyebar sehinggga menimbulkan jumlah kasus atau kematian meningkat di Indonesia. Hal ini merupakan bentuk upaya penanggulangan Pemerintah sebagai bentuk upaya melindungi kesehatan masyarakat mengingat belum ada vaksin untuk mengatasi Covid-19.
Undang-Undang No. 6 Tahun 2018 tentang Kekarantinaan Kesehatan yang menyatakan bahwa "Kekarantinaan Kesehatan adalah upaya mencegah dan menangkal keluar atau masuknya penyakit dan/atau faktor risiko kesehatan masyarakat yang berpotensi menimbulkan kedaruratan kesehatan masyarakat". Karantina merupakan pembatasan kegiatan dengan artian untuk memisahhkan seorang yang terkena atau terpapar penyakit menular yan ditetapkan dalam peraturan perundang-undangan walaupun belum terdapat gejala atau sedang ada dalam fase inkubasi baik pemisahan peti kemas, alat atau barang yang diduga terkontaminasi dari seorang yang merupakan sebab adanya penyakit atau sumber kontaminasi lain yang bertujuan untuk mencegah kemungkinan adanya penyebaran kepada orang lain atau barang disekitarnya. Karantina tidak hanya dilakukan di darat saja melainkan juga dapat dilakukan pada laut serta udara adanya karantina dikarenakan adanya suatu penyakit yang menular baik dari seseorang atau barang 
disekitarnya kepada orang lain. kesehatan masyarakat yang dapat Adapun tujuan kekarantinaan menimbulkan kedaruratan kesehatan kesehatan ini yaitu 1) melindungi masyarakat, 3) peningkatan masyarakat dari penyakit, resiko ketahanan nasional dalam bidang yang dapat menimbulkan kesehatan masyarakat, dan 4) kedaruratan kesehatan masyarakat, pemberian perlindungan serta 2) melakukan pencegahan dan kepastian hukum bagi masyarakat menyangkal penyakit, faktor resiko dan petugas kesehatan. 


\section{DAFTAR PUSTAKA}

\section{Jurnal/Artikel}

Mona, N. (2020) Konsep Isolasi

Dalam Jaringan Sosial Untuk

Meminimalisasi Efek

Contagious (Kasus Penyebaran

Virus Corona Di Indonesia),

Universitas Indonesia, Jakarta.

Adityo Susilo. Jurnal Penyakit

Dalam Indonesia Vol. 7, No. 1

Maret 2020

Eleanor

D. Kinney, "The

International Human Right to

Health", dalam Indiana Law

Review, Vol 34, 1559.

\section{Peraturan Perundang-Undangan}

Undang-Undang No. 4 Tahun 1984

tentang Wabah Penyakit

Menular

Undang-Undang No. 6 Tahun 2018

tentang

Kekarantinaan

Kesehatan

Keputusan Presiden Republik

Indonesia No. 11 Tahun 2020 tentang
Penetapan Kedarutan Kesehatan

Masyarakat Corona Virus

Disease 2019 (COVID-19)

Peraturan Menteri Kesehatan No. 1501/MENKES/PER/X/2010

tentang Jenis Penyakit Menular

Tertentu Yang Dapat

Menimbulkan Wabah Dan

Upaya Penanggulangan

\section{Website}

Lidwina, A. (2020) Covid-19 Dari Wabah Jadi Pandemi (Diakses, 25 Mei 2020) https://katadata.co.id/infografik/ 2020/03/16/covid-19-dariwabah-jadi-pandemi

Sebayang, R. (2020) WHO

Nyatakan Wabah COVID-19 Jadi Pandemi (Diakses, 25 Mei 2020)

https://www.cnbcindonesia.com/ news/20200312075307-4-

144247/who-nyatakan-wabahcovid-19-jadi-pandemi-apamaksudnya

https://www.hukumonline.com/berita /baca/lt5e37cf05bee76/jika- 
virus-corona-menyebar--

pahami-beberapa-regulasi-yang-

relevan?page $=$ all

https://www.smh.com.au/world/euro

pe/china-should-be-sued-for-6- 5-trillion-for-coronavirus-

damages-says-top-uk-think-

tank-20200405-p54h5b.html 